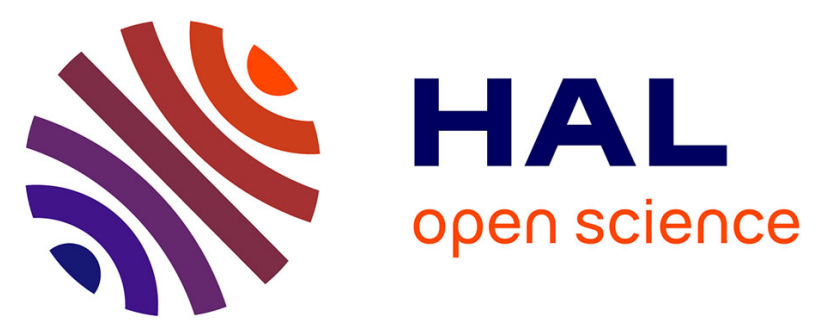

\title{
The Local Atomic Structure Study of Ordered Fe3Si and Disordered by Grinding Fe75Si25 Alloys with EXAFS and Mössbauer Techniques
}

E. Voronina, A. Deev, V. Fomin, E. Yelsukov

\section{- To cite this version:}

E. Voronina, A. Deev, V. Fomin, E. Yelsukov. The Local Atomic Structure Study of Ordered Fe3Si and Disordered by Grinding Fe75Si25 Alloys with EXAFS and Mössbauer Techniques. Journal de Physique IV Proceedings, 1997, 7 (C2), pp.C2-1003-C2-1004. 10.1051/jp4:19972116 . jpa-00255174

HAL Id: jpa-00255174

https://hal.science/jpa-00255174

Submitted on 1 Jan 1997

HAL is a multi-disciplinary open access archive for the deposit and dissemination of scientific research documents, whether they are published or not. The documents may come from teaching and research institutions in France or abroad, or from public or private research centers.
L'archive ouverte pluridisciplinaire HAL, est destinée au dépôt et à la diffusion de documents scientifiques de niveau recherche, publiés ou non, émanant des établissements d'enseignement et de recherche français ou étrangers, des laboratoires publics ou privés. 


\title{
The Local Atomic Structure Study of Ordered $\mathrm{Fe}_{3} \mathrm{Si}$ and Disordered by Grinding $\mathrm{Fe}_{75} \mathrm{Si}_{25}$ Alloys with EXAFS and Mössbauer Techniques
}

\author{
E.V. Voronina, A.N. Deev, V.M. Fomin* and E.P. Yelsukov* \\ Udmurt State University, Izhevsk 426037, Russia \\ * PhTI UrB RAS, 132 Kirov Str., Izhevsk 426001, Russia
}

\begin{abstract}
The ordered $\mathrm{Fe}_{3} \mathrm{Si}$ and disordered $\mathrm{Fe}_{3} \mathrm{Si}_{2}$, alloys are studied by $\mathrm{X}$-ray diffraction, Mössbauer spectroscopy and EXAFS -analysis. The X-ray diffraction pattern and Mössbauer spectrum of the Fe7sSi2s alloy in comparison with those of the ordered sample give evidence for the set of local atomic configurations of Fe atom and are characteristic for the disordered $b c c$ samples of the Fe-Si system. The comparison of $\chi(\mathbf{k})$ in these alloys shows noticeable differences, especially in $3.5-5 \AA^{-}$ ${ }^{1}$ region. Combining all the data obtained with the model $\chi(\mathrm{k})$ one can draw the conclusion that the changes in the Fe atom local structu-re of the $\mathrm{Fe}_{73} \mathrm{Si}_{25}$ alloy are connected with breaking a long-range order but do not correspond to a chaotic distribution of atoms.
\end{abstract}

\section{Introduction}

The local atomic stucture study of nonordered system "transition metal-metalloid" is of a considerable interest for understanding its influence on physical properties. While a great deal of experimental data on the local atomic structure obtained by numerous structure-sensitive techniques has been accumulated, for microcrystalline and nanocrystalline metastable disordered binary systems of $\mathrm{Fe}$ - sp-element there is a lack of information from direct structural methods. It is known that mechanical grinding allows to obtain microcrystalline $\mathrm{Fe}$ alloys with $\mathrm{Al}, \mathrm{Si}$ in a monophase disordered state over a wide concentration range (up to $60-70$ at.\% sp-element). The manners of the description of the concentration behaviour of thei magnetic characteristics are based on various hypotheses on the local atomic structure: a chemical short-range order [1], the change of the effective coordination number in the nearest surrounding [2], the distribution of grains in sizes within a nanometric scale [3]. That is why in this work we combine both common methods yielding data on macrostructure (X-ray diffraction) and indirect data on local structure (Mössbauer spectroscopy) with EXAFS measurements. One of the alloys studied is a characteristic for equilibrium crystalline compounds ( $\mathrm{Fe}_{3} \mathrm{Si}$ ) while the other one - for metastable disordered systems $\left(\mathrm{Fe}_{75} \mathrm{Si}_{25}\right)$. This pair is a good model sample to trace order-disorder changes.

\section{Experimental}

The Fe alloys with 25 at.\% $\mathrm{Si}$ were melt from $\mathrm{Fe}$ and $\mathrm{Si}$ of high purity in an Ar induction furnace. Then the $\mathrm{Fe}_{75} \mathrm{Si}_{25}$ alloy was ground in a ball mill for $30 \mathrm{~h}$ in an argon atmosphere. The $\mathrm{Fe}_{3} \mathrm{Si}$ alloy was obtained from the ground alloy by annealing for $1 \mathrm{~h}$ at $800^{\circ} \mathrm{C}$ and then for $10 \mathrm{~h}$ at $400^{\circ} \mathrm{C}$. Both samples were tested by X-ray diffraction and Mössbauer spectroscopy. X-ray diffraction analysis was performed using filtered $\mathrm{Fe}-\mathrm{K}_{\alpha}$ radiation. The Mössbauer spectra on ${ }^{57} \mathrm{Fe}$ nuclei were taken with a ${ }^{57} \mathrm{Co}$-source in a chromium matrix at the temperatures 300 and $80 \mathrm{~K}$. The monophase state of the samples was also checked in the measurement of temperature dependence of magnetic susceptibility.The EXAFS-experiment was performed with a laboratory spectrometer RAS-1 at $\mathrm{T}=300 \mathrm{~K}$ using a Mo-tube and bent ( $13 \overline{4} 0$ ) $\mathrm{SiO}_{2}$ crystal-monochromator.

\section{Results and discussion}

$\mathrm{X}$-ray diffraction patterns for the $\mathrm{Fe}_{3} \mathrm{Si}$ (a) and $\mathrm{Fe}_{75} \mathrm{Si}_{25}$ (b) samples given in Fig. 1 show that both of them are monophase. In the $\mathrm{Fe}_{3} \mathrm{Si}$ pattern besides bcc phase peaks there are $\mathrm{DO}_{3}$ superlattice (111) and (200) peaks of equal intensity (marked "थ!") proving that the chemical long-range order parameters are close to the maximum for this superlattice in stoichiometric alloy. For the $\mathrm{Fe}_{75} \mathrm{Si}_{25}$ alloy there are only broadened peaks of $b c c$ structure. The lattice parameters calculated for them are close and equal to $1 / 2 \overline{\mathrm{a}}\left(\mathrm{Fe}_{3} \mathrm{Si}\right)=2.82545 . \AA$ and $\overline{\mathrm{a}}\left(\mathrm{Fe}_{75} \mathrm{Si}_{25}\right)=2.8368 \AA$, respectively. The Mössbauer spectra and restored from them hyperfine magnetic field distribution functions $\mathrm{P}(\mathrm{H})$ are shown in Fig.2. For the $\mathrm{Fe}_{3} \mathrm{Si}$ compound (a) they consist of only 2 sextets and 2 peaks in $P(H)$, corresponding to 2 nonequivalent configurations of the $\mathrm{Fe}$ atom: 1- with $8 \mathrm{Fe}$ atoms and 2 - with $4 \mathrm{Fe}$ and $4 \mathrm{Si}$ atoms nearest neighbours. The Mössbauer spectrum and $\mathrm{P}(\mathrm{H})$ of $\mathrm{Fe}_{75} \mathrm{Si}_{25}$ are characteristic of a disordered state with a set of nonequivalent surroundings of the Fe atom. Preceding mathematical processing of the spectrum also showed that the probabilities of $\mathrm{Fe}$ atom nearest surroundings differed from the chaotic distribution of the $\mathrm{Fe}$ and $\mathrm{Si}$ 
atoms in a $b c c$ lattice with coordination number of the nearest atoms $Z=8$. Mössbauer study of the $b c c$ Fe-Si alloys [1] allowed to conclude that the considerable changes of the local atomic structure in the two nearest spheres took place on increasing the Si concentration. The same thing is testified by the comparison of the normalized oscillating parts $\chi(\mathrm{k})$ of the disordered bcc alloys $\mathrm{Fe}_{85} \mathrm{Si}_{15}$ and $\mathrm{Fe}_{67} \mathrm{Si}_{33}$ (Fig.3,d,e) with that of the $\mathrm{Fe}_{75} \mathrm{Si}_{25}$ alloy (Fig.3,c). What kind of the changes appear can be seen from EXAFS measurements of the ordered $\mathrm{Fe}_{3} \mathrm{Si}$ and disordered $\mathrm{Fe}_{75} \mathrm{Si}_{25}$ alloys shown in Fig.3.

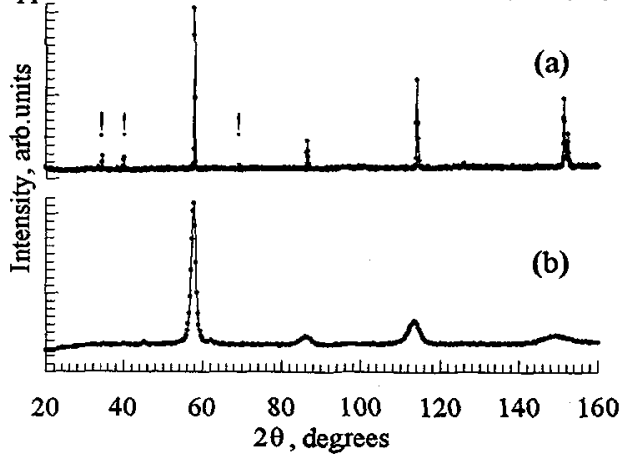

Figure 1: X-ray diffraction patterns $\mathrm{Fe}_{3} \mathrm{Si}$ and $\mathrm{Fe}_{75} \mathrm{Si}_{25}$ alloys.

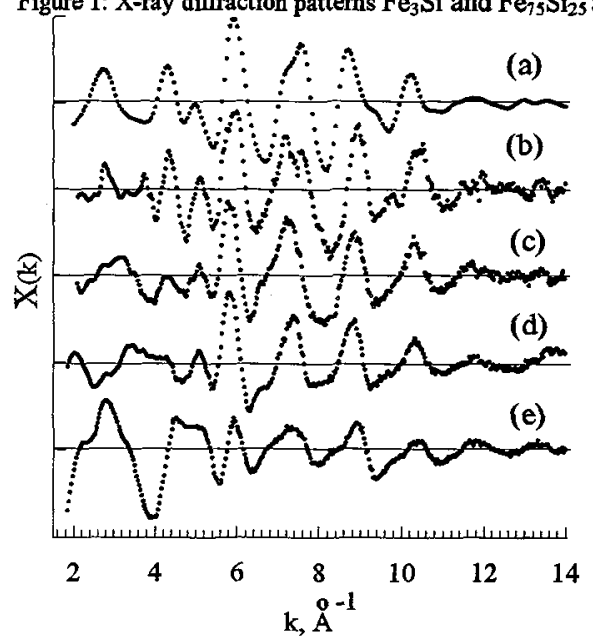

Figure 3: Model $\chi(\mathbf{k})$ (a), and experimental $\chi(\mathbf{k})$ for $\mathrm{Fe}_{3} \mathrm{Si}(\mathbf{b})$, for $\mathrm{Fe}_{75} \mathrm{Si}_{25}$ (c), for $\mathrm{Fe}_{85} \mathrm{Si}_{15}$ (d) and for $\mathrm{Fe}_{67} \mathrm{Si}_{33}$ (e).

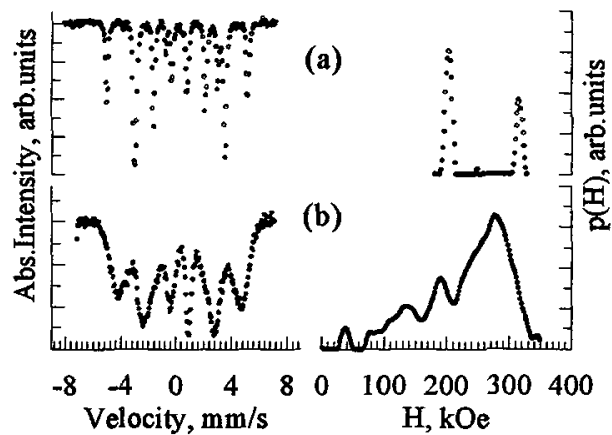

Figure 2: Mössbauer spectra and $\mathrm{P}(\mathrm{H})$ of $\mathrm{Fe}_{3} \mathrm{Si}_{,} \mathrm{Fe}_{75} \mathrm{Si}_{25}$ alloys.

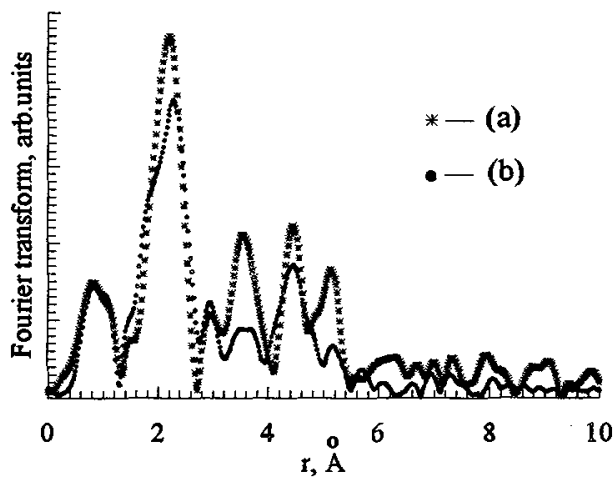

Figure 4: The Fourier transform of EXAFS for $\mathrm{Fe}_{3} \mathrm{Si}$ (a) and for $\mathrm{Fe}_{5} \mathrm{Si}_{25}$ (b).

Comparing $\chi(\mathrm{k})$ (b) and (c) it is seen that the main differences take place in the $3.5-5 \AA^{-1}$ region, where the backscattering amplitude values of the $\mathrm{Si}$ atom is higher than those of the Fe atom. The model $\chi(\mathrm{k})$ the Fe $\mathrm{Si}$ compound calculated with model partial radial distribution functions (RDF) of ideal $\mathrm{DO}_{3}$ superlattice (Fig.3,a) is seen to be in a good agreement with the experimental one. Some trivial models of $\mathrm{RDF}$ for the disordered alloy $\mathrm{Fe}_{75} \mathrm{Si}_{25}$ corresponding to chaotic atoms distribution do not explain the differnces observed in $\chi(k)$. Fourier transform analysis results for both alloys (Fig.4) reflect the fact that there are some changes in the first two spheres and the noticable changes in the next spheres confirm breaking the chemical long-range order. All of that allows to make only a qualitative evaluation of the change of the local chemical arrangement. To obtain correct detailed information on partial RDF some more structure experiments will be essential.

\section{Acknowlegements}

The authors are grateful to Dr. Yu. Ruts, Prof. Yu. Babanov, Dr. A. Ageev, Dr. D. Guy for the helpful discussions and interest in the work and to Dr.Tyliszczak for mathematical processing program.

\section{References}

[1] E.P. Elsukov et al., J. Phys: Cond. Matter 4 (1992) 7597-7603.

[2] A K. Arznikov et al., JMMM 153 (1996) 195-201.

[3] G. LeCaër et al., Mat. Sci. Forum 179-181 (1995) 469-474. 